the Commonwealth Scientific and Industrial Research Organization. These will be added to the comprehensive collection of the Organization's Division of Entomology and will become part of the Australian National Insect Collection. Mr. Rayment has earned world-wide recognition as an authority in the Hymenoptera, especially the Aphidae, both for his work in classifying the Australian species of the latter, and for his interesting studies on their biology. The collection is regarded as a very important addition to the National Collection as it contains many type specimens and hence will be widely used for reference work.

\section{Harkness Fellowships of the Commonwealth Fund}

Thirty Harkness Fellowships of the Commonwealth Fund are tenable for 1961 in Continental United States and are offered, in separate series, to candidates from the United Kingdom, Australia and New Zealand, and Western Europe. The Fellowships are offered to candidates from the United Kingdom who are British subjects and either are graduates or have experience in government service, the professions, the creative arts, journalism, branches of business or industry, or other comparable careers and vocations, and have the equivalent of a degree in qualifications conferred by professional bodies or an attested level of professional accomplishment. Forms of application, which must be returned before December 1, can be obtained from the Warden, Harkness House, 38 Upper Brook Strect, London, W.1, from whom further details can be obtained.

\section{The Association of Consulting Scientists}

THE following have been elected honorary officers and members of the Council of the Association of Consulting Scientists for 1960-61: Chairman, Dr. J. G. Davis; Honorary Treasurer, Dr. G. W. Ferguson; Honorary Secretary, Mr. W. H. Stevens; Members, Dr. M. Barent, Dr. H. H. Chambers, Dr. J. Grant, Dr. J. H. Oliver, Mr. O. W. Roskill, Mr. F. G. Sarel Whitfield.

\section{Medical Research Council: Tropical Medicine Research Board}

THE Medical Research Council recently established a Tropical Medicine Research Board to advise them on the promotion and co-ordination of all research in this field. The membership of the Board includes the following: Sir Harold Himsworth (chairman); Prof. A. C. Frazer (vice-chairman); Brigadier Sir John Boyd; Prof. P. C. C. Garnham; Prof. W. E. Kershaw ; Dr. R. Lewthwaite; Prof. G. Macdonald; Prof. B. G. Maegraith; Prof. B. S. Platt; Prof. M. L. Rosenheim ; Mr. H. J. Seddon; Prof. E. T. C. Spooner ; Prof. A. W. Woodruff; Dr. B. S. Lush (secretary). The Chief Medical Officer and the Head of the Research Department of the Colonial Office have been appointed assessors on the Board, and two assessors have been nominated by the Secretary of State for Commonwealth Relations.

\section{Medical Research Council: New Members}

The Committee of Privy Council for Medical Research has re-appointed the Right Hon. the Earl of Limerick and, in succession to Sir Geoffrey Vickers, have appointed Dr. E. F. Collingwood to membership of the Medical Research Council. Lord Limerick will continue as chairman of the Council and Dr. Colling- wood will serve as treasurer. Prof. T. Crawford and Prof. W. M. Millar have been appointed members of the Council in succession to Prof. G. Payling Wright and J. D. N. Hill, who are retiring after their normal four-year term of service. All these appointments dated from October 1, 1960.

\section{Announcements}

Prof. B. Bleaney and Dr. James Cook have been appointed members of the Council for Scientific and Industrial Research. Together with a third member yet to be appointed, they succeed Prof. P. M. S. Blackett, Sir Eric Ashby and Mr. H. Douglass, who have retired on completion of their period of service.

Dr. J. M. WINTERBotToM has been appointed director of the Percy Fitzpatrick Institute of African Ornithology, University of Cape Town, and took up his office there on September 1.

DR. W. S. STILEs has been elected president of the Illuminating Engineering Society for 1960-61. Dr. Stiles is a deputy chief scientific officer at the National Physical Laboratory, which he joined in 1925. His work in the past has included problems of vision, photometry, illuminating engineering, and visual response by psychophysical methods; his discovery with Dr. B. H. Crawford of the directional sensitivity of the retina being his best-known contribution. He was elected to fellowship of the Royal Society in 1957 for his work on vision.

The first major exhibition on atomic energy to be held in Edinburgh opened at the Royal Scottish Museum on October 15. The exhibition, which has been mounted by the Atomic Energy Authority, will continue until October 29 ; it will provide a comprehensive review of Britain's nuclear power programme and of Scotland's contribution to this major scientific and industrial effort. The exhibition will illustrate the way in which Britain's research and development resources are being deployed to meet the future power needs. These are likely to be well over double the present level, expressed in terms of coal equivalent, by 1975 .

THe ninth International Colloquium on Spectroscopy will be held at Lyon during June 5-10, 1961, under the auspices of the 'Groupement pour l'Avancement des Méthodes Spectrographiques'. Further information is available from Groupement pour l'Avancement des Méthodes Spectrographiques L.N.E., 1, rue Gaston-Boissier, Paris $15 \mathrm{e}$.

The twenty-first International Conference of Pure and Applied Chemistry will be held during August $2-5,1961$, and will be followed by the eighteenth International Congress of Pure and Applied Chemistry during August 6-12. Both meetings will be held in Montreal. Further information is available from the Secretariat, National Research Council, Ottawa, Canada.

A THREE-DAY symposium on Control of the Mind is being organized by the Medical Center of the University of California at San Francisco during January 28-30, 1961. The symposium is being organized with financial aid from the Schering Foundation. Further information can be obtained from the Department of Continuing Education in Medicine, University of California, Medical Center, San Francisco 22. 